J. Lake Sci. (湖泊科学), 2014, 26(1):66-73

http : //www. jlakes. org. E-mail : jlakes@niglas. ac.cn

(c) 2014 by Journal of Lake Sciences

\title{
松原灌区建设对查干湖生态风险分析及对策”
}

孙广友 ${ }^{1,2,3}$, 田 卫 $^{1}$, 贾志国 ${ }^{4}$, 王海霞 ${ }^{5}$, 马广庆 ${ }^{1}$, 毕淑霞 ${ }^{4}$, 徐 宁 $^{1}$, 王军海 ${ }^{4}$, 姚允龙 ${ }^{6}$

( 1 : 中国科学院东北地理与农业生态研究所, 长春 130012)

( 2 : 吉林大学环境与资源科学学院, 长春 130026$)$

(3: 哈尔滨学院, 哈尔滨 150086 )

( 4 : 吉林省水利水电勘测设计研究院, 长春 130012)

$(5:$ 东北师范大学, 长春 130024$)$

(6:东北林业大学,哈尔滨 150086 )

摘 要: 松原灌区将对国家自然保护区查干湖周围的盐碱地实施大面积围旺, 若大量高浓度碱性尾水直排人湖, 将导致 查干湖生态系统严重污染. 对这一风险合理评估并防范, 关系到湖区生态安全与灌区的可行. 本文在对湖区生态环境及 灌区尾水排放模式与含盐特性系统分析基础上, 提出利用退化沼泽湿地 (盐沼) 构建湿地处理系统 (生态缓冲区), 而非直 接人湖的构想. 当灌区运行一定时期, 尾水水质得到改善, 再人湖发挥补水效应. 同时在设计上采取盐碱地分批滚动开 发, 以控制年排盐总量, 降低排盐强度; 以及充分利用碱湖泡随机承泄, 减轻对查干湖的压力, 既可防止湖水污染, 又可保 证灌区建设可行.

关键词: 松原灌区;查干湖;盐碱地开发;生态风险分析;湿地处理系统

\section{Risk analysis and mitigation on the impact of the development of Songyuan Irrigation area on the ecology of Lake Chagan}

SUN Guangyou ${ }^{1,2,3}$, TIAN Wei ${ }^{1}$, JIA Zhiguo ${ }^{4}$, WANG Haixia ${ }^{5}$, MA Guangqing ${ }^{1}$, BI Shuxia ${ }^{4}$, XU Ning ${ }^{1}$, WANG Junhai ${ }^{4} \&$ YAO Yunlong ${ }^{6}$

(1: Northeast Institute of Geography and Agriculture Ecology, Chinese Academy of Sciences, Changchun 130012, P. R. China)

(2: College of Environment and Resource Science, Jilin University, Changchun 130026, P. R. China)

(3: Harbin University, Harbin 150086, P. R. China)

(4: Water Conservancy and Hydroelectricity Design Institute of Jilin Province, Changchun 130012, P. R. China)

(5: Northeast Normal University, Changchun 130024, P. R. China)

(6: Northeast Forest University, Harbin 150086, P. R. China)

Abstract: In order to increase food supply and suppress the ecological degradation, the saline-alkaline land surrounded the Lake Chagan will be developed into the largest irrigated area-Songyuan Irrigation area, in the Songhuajiang-Nenjiang ( Songnen) Plain. The area will be $2.84 \times 10^{7} \mathrm{~km}^{2}$. The proposed irrigated area is located in the center of saline-alkaline region of the plain. The important objectives include new rice fields, improving the existing dry land of low yields, and recovering grassland and wetland. The drained water from the irrigation area is saline-alkaline water, while the Lake Chagan is a light alkaline lake, the largest lake in the Songnen Plain, and a national natural protection zone. The plants under protection include Phragmites and Suaeda glauca (Bunge), and the animals under protection include Ciconia, Grus leucogeranus, Gruiformes, Aquila chrysaetos, etc. Most birds in the region belong to the first class national protected animals or endangered species. Therefore, the lake is an important base for the biological species and plays an important environmental function in accommodating local climate. In this area, the ecological systems have been seriously degraded, so that some of the land has become the alkaline deserts. Since the Lake Chagan is a conflux

* 吉林省水利厅哈达山水利枢纽主要配套工程松原灌区规划项目 (吉水规计 [40]) 资助. 2012-10-16 收稿;201305-28 收修改稿. 孙广友(1939 ), 男, 研究员;E-mail:sun_guangyou@163.com. 
center for the ground and surface water, if the tailing water of the irrigation engineering is pumped into the lake directly, the lake biological system would be in serious aftermath. Thus the key issue is how to avoid the ecological risk that the development the irrigation area might bring to the Lake Chagan. For getting both the benefits of protecting the lake biological system and developing the saline-alkaline land, this paper, based on analyses of the risks, has designed five wetland disposal systems as the transition area to deal with the alkaline tailing water. First of all, through degrading and precipitating of the pollutants, the $\mathrm{pH}$ of the tailing water was decreased when it enters into the modeling water processing systems. If the salt contents need to be decreased, the tailing water should be mixed with the water deriving from the Songhua River. Only when the tailing water quality meets the standard, the water will be allowed to discharge into the lake. The hazard evaluation indicates that this utilization model would not only not damage the lake ecosystem, but also be conducive to the stabilization of the lake ecosystem. Furthermore, the utilization model could develop saline-alkaline region and promote social economic development in the area.

Keywords: Songyuan Irrigation area; Lake Chagan; development of saline-alkaline land; ecological risk analysis; wetland treatment system

目前, 吉林省西部的松原、大安、引嫩人白三大灌区, 以及黑龙江省西部的引嫩综合工程正在同期建设, 松嫩平原盐碱地进人了大规模开发的历史时期 ${ }^{[1]}$. 因此, 合理控制尾水排放以避免河湖水体污染, 就成为这 些灌区开发能否成功的关键性生态问题.

松原灌区是国家粮食基地建设的组成部分, 意义重大. 但区位上却是对查干湖外围大面积苏打盐碱地的 围垦. 查干湖作为松嫩平原第一大湖, 已列人国家自然保护区. 如果将高浓度盐碱尾水直接泄人湖内, 无疑将 造成湖区污染, 生态后果严重. 因此, 科学分析并防范这一生态风险, 对保护该湖生态环境极其重要, 也是灌区 可行性的基础. 而目前有关查干湖生态系统的研究报告均未涉及盐碱地围叚下的环境保护 (1) 发表的论文也 多侧重于湖泊生态分析或面源污染的一般性研究 ${ }^{[24]}$; 仅有个别研究涉及到稻田尾水中农药排放对湖水水 质的影响 ${ }^{[5]}$, 但尚无松原灌区盐碱性尾水排放对查干湖生态综合影响以及风险控制的专门性研究.

本文基于生态规划原则 ${ }^{[6-7]}$, 系统分析了松原灌区盐碱物质排放对查干湖可能产生的生态风险, 并首次 提出了利用湖泊外围退化沼泽湿地构建湿地水处理系统, 从而对盐碱地大规模开发可能引发的生态风险进 行控制的新思路, 解决了既使查干湖的生态环境得到保护, 又使松原灌区建设能够实施的焦点矛盾, 并成为 灌区规划的重要科学依据.

\section{1 查干湖区生态环境}

\section{1 湖区尺度大、水量失衡}

查干湖原属于全新世中期大安古河道的南段, 经地壳缓慢沉降, 与人湖的霍林河一起失去外泄条件而演 变为内流湖, 降水与霍林河洪水为主要补给水源. 因干旱和截流, 霍林河的人湖径流量在 1957-1998 年期间, 曾有 20 年接近于零, 导致湖面萎缩. 为此, 建设了通过新庙的第二松花江补水渠道, 兼接纳因长期开发而浓度 大为降低的前郭灌区尾水, 年人湖量 $3.56 \times 10^{8} \mathrm{~m}^{3}$, 使湖水位高程保持在海拔 $130 \mathrm{~m}$. 此时, 查干湖的面积为 $347.4 \mathrm{~km}^{2}$, 平均水深为 $1.56 \mathrm{~m}$, 最大水深为 $3.50 \mathrm{~m}$, 相应容积为 $5.42 \times 10^{8} \mathrm{~m}^{3}$. 而且, 原来与查干湖分离的 新庙泡和新甸泡彼此联通为统一水体,形成了查干湖的完整体系 (表 1 ) 2).

\section{表 1 查干湖系统主要特性}

Tab. 1 The main features of Lake Chagan system

\begin{tabular}{cccccc}
\hline 湖泡 & 水域面积 $/ \mathrm{hm}^{2}$ & 平均水深 $/ \mathrm{m}$ & $\mathrm{pH}$ & 主要功能 & 主要生态问题 \\
\hline 查干湖 & 25560 & 1.6 & 7.5 & 调洪、生物基因库、旅游、芦苇、渔场 & 生态退化 \\
新庙泡 & 2389 & 1.5 & 8.8 & 旅游、补水、芦苇、渔场 & 旅游污染 \\
库里泡 & 1441 & 2.0 & 7.8 & 泄水通道、净化、芦苇、渔场 & 生态退化 \\
新甸泡 & 1080 & 1.0 & $>8.5$ & 储水、生态缓冲、芦苇、渔场 & 生态退化 \\
\hline
\end{tabular}

(1) 北京大学城市与环境学院. 查干湖旅游度假区暨中心区控制性规划,2002:1-5.

(2) 孙广友, 孟宪告, 杨富亿等. 查干湖生态系统及渔苇业开发对策综合研究报告, 1992:1-70. 
由于环境变化, 目前查干湖每年仍缺水 $1.0 \times 10^{8} \sim 2.0 \times 10^{8} \mathrm{~m}^{3}$, 水位已降至 $129.2 \mathrm{~m}$ 左右, 水质也有恶 化趋势, 特别是枯水期碱度增高, 因此增加水量补给仍是迫切问题.

\section{2 半干旱、生物多样性丰富}

查干湖保护区的划定面积为 $50684 \mathrm{hm}^{2}$, 外围保护带为 $14666 \mathrm{hm}^{2}$. 保护目标为使查干湖为半干旱气候 带湖泊水生生态系统和湿地生态系统. 湖区植被的维管束植物有 292 种, 隶属于 61 科 190 属, 建群种、优势 种和主要伴生种皆为碱性中旱生植物; 典型植被为芦苇和碱蓬群落 ${ }^{[8]}$. 查干湖有鸟类 239 种, 其中国家 I 级 (东方白鹳等 8 种)、II 级 (大天鹅等 35 种) 重点保护的鸟类 43 种, 具有稀有性和濒危性. 两栖爬行类 9 种、 鱼类 46 种、昆虫 446 种. 查干湖生物多样性丰富,组成了独特的生物基因库.

\section{3 复合型盐碱湿地}

查干湖是由弱碱性湖泊湿地、中一重度碱性芦苇沼泽湿地 (湖滩) 和碱性河流湿地 (霍林河口) 构成的湿 地复合体, 在中国具有典型性, 具有水体核心带、芦苇湿地缓冲带与外围盐沼带的层圈性湿地景观. 该湖发 育于沉降湖盆, 是松辽分水岭北斜面地表物质流的汇聚中心 ${ }^{[9]}$. 湖体储纳地表水、矿物质和可溶盐, 并对芦 苇沼泽直接补给; 而芦苇又对外围以碱蓬、虎尾草为代表的顶极盐沼群落向湖输送的物质起到过滤、降解和 沉淀作用, 对湖体环境发挥稳定效应, 共同形成盐沼湿地多异质共生结构. 亦表征该内陆盐碱湿地景观发育 到高级阶段,具有内陆型盐碱湿地的典型性.

\section{4 生态系统脆弱性突出}

1.4. 1 水质呈弱碱性, 函待改善 查干湖属于重碳酸盐类纳组 I 型微咸水富营养湖泊 ${ }^{[10]}$. 查干湖水质季节 分异明显, 夏季丰水期, 矿化度平均为 $0.91 \mathrm{~g} / \mathrm{L}, \mathrm{pH}$ 为 8.2 (表 2); 枯水期碱性加重, $\mathrm{pH}$ 平均为 9.0. 可见, 对 查干湖的水质加以控制是必要的.

表 2 查干湖夏季丰水期化学特征 (霍林河口至新庙泡断面) (1) *

Tab. 2 The chemical features in summer of wet season of Lake Chagan

(from the mouth of Huolin River to Lake Xinmiao section)

\begin{tabular}{|c|c|c|c|c|c|c|c|c|c|c|c|c|}
\hline \multirow{2}{*}{ 样号 } & \multicolumn{4}{|c|}{ 阴离子/ $(\mathrm{mg} / \mathrm{L})$} & \multicolumn{4}{|c|}{ 阳离子/ $(\mathrm{mg} / \mathrm{L})$} & \multirow{2}{*}{$\mathrm{pH}$} & \multirow{2}{*}{$\begin{array}{c}\text { 矿化度/ } \\
(\mathrm{g} / \mathrm{L})\end{array}$} & \multirow{2}{*}{ SAR } & \multirow{2}{*}{ 水化学类型 } \\
\hline & $\mathrm{CO}_{3}^{2-}$ & $\mathrm{HCO}_{3}^{-}$ & $\mathrm{Cl}^{-}$ & $\mathrm{SO}_{4}^{2-}$ & $\mathrm{Ca}^{2+}$ & $\mathrm{Mg}^{2+}$ & $\mathrm{Na}^{+}$ & $\mathrm{K}^{+}$ & & & & \\
\hline 1 & 104.0 & 593.4 & 159.8 & 54.33 & 16.77 & 18.09 & 276.0 & 2.77 & 8.6 & 1.26 & 66.11 & $\mathrm{HCO}_{3}^{-}-\mathrm{Na}^{+}-\mathrm{Cl}^{-}$ \\
\hline 2 & 127.6 & 504.6 & 158.4 & 33.49 & 17.71 & 13.75 & 258.8 & 3.18 & 8.4 & 1.12 & 65.25 & $\mathrm{HCO}_{3}^{-}-\mathrm{Na}^{+}-\mathrm{Cl}^{-}$ \\
\hline 3 & 139.4 & 463.3 & 111.8 & 53.21 & 15.69 & 15.92 & 307.1 & 3.6 & 8.2 & 1.11 & 77.25 & $\mathrm{HCO}_{3}^{-}-\mathrm{CO}_{3}^{2-}-\mathrm{Cl}^{-}$ \\
\hline 4 & 141.8 & 478.6 & 148.7 & 37.21 & 15.22 & 13.37 & 317.4 & 3.32 & 8.4 & 1.16 & 83.84 & $\mathrm{HCO}_{3}^{-}-\mathrm{CO}_{3}^{2-}-\mathrm{Cl}^{-}$ \\
\hline 5 & 128.8 & 484.0 & 149.4 & 51.72 & 19.88 & 14.32 & 320.9 & 3.04 & 8.3 & 1.18 & 77.60 & $\mathrm{HCO}_{3}^{-}-\mathrm{Na}^{+}-\mathrm{Ca}^{2+}$ \\
\hline 6 & 122.9 & 482.2 & 145.3 & 47.63 & 17.08 & 16.76 & 303.6 & 2.91 & 8.4 & 1.14 & 73.80 & $\mathrm{HCO}_{3}^{-}-\mathrm{Na}^{+}-\mathrm{Cl}^{-}$ \\
\hline 7 & 26.00 & 239.8 & 23.17 & 54.70 & 33.86 & 23.64 & 65.1 & 1.94 & 8.0 & 0.49 & 12.14 & $\mathrm{HCO}_{3}^{-}-\mathrm{SO}_{4}^{2-}-\mathrm{Na}^{+}-\mathrm{Ca}^{2+}$ \\
\hline 8 & 14.18 & 242.3 & 13.83 & 2.23 & 38.14 & 12.06 & 57.5 & 1.80 & 7.9 & 0.33 & 13.36 & $\mathrm{HCO}_{3}^{-}-\mathrm{Na}^{+}-\mathrm{Ca}^{2+}$ \\
\hline 9 & 11.82 & 237.6 & 12.45 & 10.42 & 38.52 & 12.62 & 51.5 & 1.94 & 7.8 & 0.39 & 10.18 & $\mathrm{HCO}_{3}^{-}-\mathrm{CO}_{3}^{2-}-\mathrm{Cl}^{-}$ \\
\hline 平均 & 90.72 & 413.98 & 102.54 & 38.33 & 23.65 & 15.50 & 217.5 & 2.72 & 8.2 & 0.91 & 53.28 & $\mathrm{HCO}_{3}^{-}-\mathrm{Na}^{+}-\mathrm{Cl}^{-}$ \\
\hline & & & & & & & & & & & & $\mathrm{HCO}_{3}^{-}-\mathrm{Na}^{+}-\mathrm{Ca}^{2+}$ \\
\hline
\end{tabular}

* 据 2009 年水质监测, 查干湖水质低于《地表水环境监测标准》III类;SAR 为钠吸收比.

1.4.2 生态环境退化 本区因处于松嫩平原盐碱地核心区, 盐碱地年增长率达到 $1.5 \%$ 2.0\%, 环境出现突 变趋势, 生态退化严重 ${ }^{[11-14]}$. 大片芦苇 (Phragmites australis var.) 群落逐渐被碱蓬 ( Suaeda glauca) 代替, 甚至 出现碱斑连片的碱质荒漠(图 1 ).

\section{2 灌区建设与生态风险}

\section{1 灌区范围、性质与结构}

灌区位于查干湖南侧与霍林河河口的低平原区, 为嫩江大安古河道与霍林河古河道交汇 ${ }^{[15-16]}$, 总面

(1) 孙广友,孟宪赤,杨富亿等. 查干湖生态系统及渔苇业开发对策综合研究报告, 1992:6-13. 


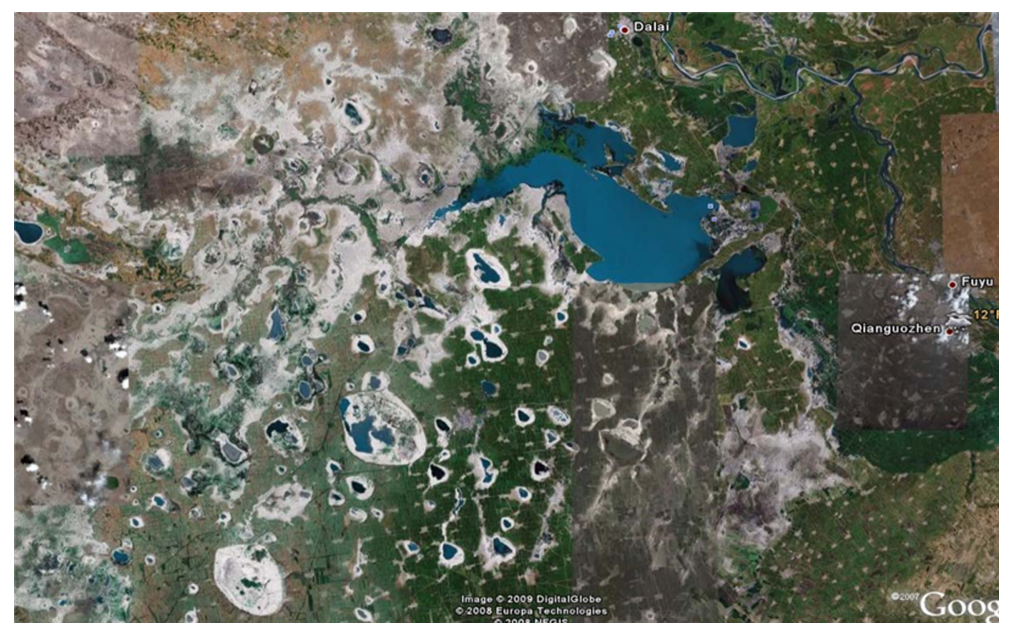

图 1 查干湖区卫星影像(据 Google 截图, 蓝色为湖泊, 白色为盐碱地)

Fig. 1 The remote sensing of Lake Chagan

( from Google, blue is lake, white is saline-alkaline land)

积为 $18.93 \times 10^{4} \mathrm{hm}^{2}$, 含水田、旱田、草原, 面积分别为 $10.61 \times 10^{4} 、 2.76 \times 10^{4} 、 30 \times 10^{4} \mathrm{hm}^{2}$. 还兼有渔业、湿 地恢复效益, 是一个以商品粮为主, 兼顾牧、渔业和湿地恢复的综合性生态灌区, 并与大安灌区等共同形成 东北第四大水稻带 ${ }^{[1,17]}$. 水源引自第二松花江哈达山水库, 另有部分地下水匹配 (图 2$)^{1}$.

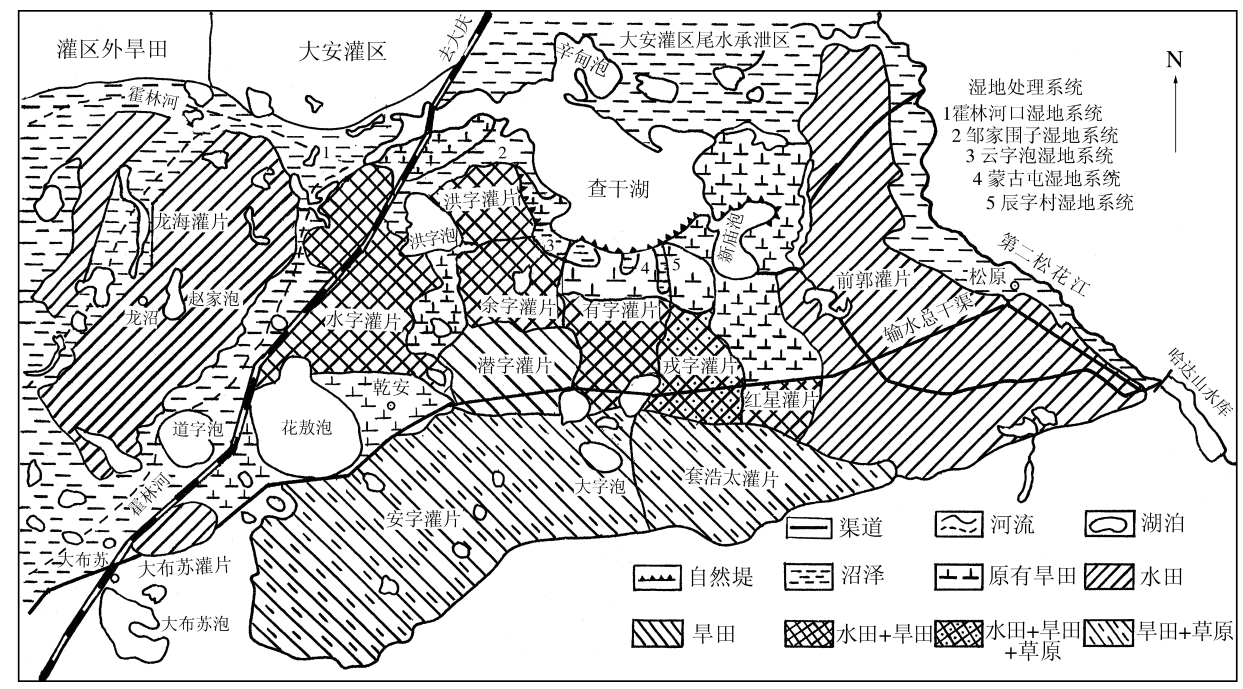

图 2 松原灌区范围(12 个灌片)结构略图

Fig. 2 The scope and construction (12 irrigation pats) of Songyuan Irrigation

\section{2 生态风险分析}

2.2.1 风险物质汇聚中心 灌区处于松辽分水岭北坡面, 最高海拔 $170.0 \mathrm{~m}$, 最低海拔 $129.5 \mathrm{~m}$. 地貌面从 东、南和西三个方向向湖区倾斜, 成为地表二维径流场的汇聚中心一一风险物质汇点. 同时, 潜水径流方向 与地表径流一致. 这样, 灌区开发后, 地表与地下可溶盐流会呈三维模式向湖区汇聚, 对湖泊生态构成威胁.

(1) 吉林省水利水电勘测设计研究院. 松原灌区规划,2010. 
2.2.2 风险源范围广 按开发规划, 灌区共划分为 12 个灌溉片 (表 3) (1).

表 3 松原灌区各片土壤类型及开发规模 $\left(\mathrm{km}^{2}\right) *$

Tab. 3 The soil type and development area of Songyuan Irrigation

\begin{tabular}{|c|c|c|c|c|c|c|c|c|c|c|}
\hline \multirow{2}{*}{ 分灌区 } & \multirow{2}{*}{ 子灌片 } & \multicolumn{2}{|c|}{ 非盐渍土 } & \multirow{2}{*}{$\begin{array}{c}\text { 盐化草甸 } \\
\text { 黑钙土 }\end{array}$} & \multicolumn{3}{|c|}{ 盐渍土复区 } & \multirow{2}{*}{ 水田 } & \multirow{2}{*}{ 旱田 } & \multirow{2}{*}{ 草原 } \\
\hline & & 淡黑钙土 & 草甸黑钻土 & & 轻度 & 中度 & 重度 & & & \\
\hline \multirow{4}{*}{ 前郭 } & 前郭片 & - & 0.06 & 0.73 & 1.08 & 0.35 & 0.17 & 4.80 & - & - \\
\hline & 红星片 & - & 0.02 & 0.21 & - & - & 0.10 & 0.08 & 0.24 & - \\
\hline & 戎字片 & - & 0.01 & 0.63 & 0.17 & - & - & 0.14 & 0.27 & 0.23 \\
\hline & 套浩太片 & - & 0.12 & 0.14 & 1.37 & 0.43 & 0.04 & - & 0.72 & 1.31 \\
\hline \multirow{7}{*}{ 乾安 } & 有字片 & 0.17 & - & 0.05 & 0.27 & - & - & 0.42 & 0.24 & - \\
\hline & 水字片 & 0.31 & - & 0.87 & 0.15 & 0.14 & 0.33 & 0.99 & 0.03 & - \\
\hline & 潜字片 & 0.42 & 0.07 & - & - & - & - & - & 0.69 & - \\
\hline & 余字片 & 0.49 & - & - & 0.03 & - & 0.16 & 0.26 & 0.46 & - \\
\hline & 洪字片 & 1.50 & - & - & 0.11 & 0.03 & 0.14 & 0.28 & 0.21 & - \\
\hline & 安字片 & 1.05 & 0.87 & 0.32 & 1.12 & 0.07 & 0.48 & - & 3.50 & 0.40 \\
\hline & 大布苏片 & 0.01 & - & - & - & 0.08 & 0.08 & 0.18 & - & - \\
\hline 大安 & 龙海片 & - & 0.05 & 0.06 & - & 1.01 & 3.53 & 3.36 & - & - \\
\hline 总计 & & 3.94 & 1.19 & 2.23 & 4.40 & 2.12 & 5.10 & 10.65 & 6.39 & 1.94 \\
\hline
\end{tabular}

* 土壤开发规模总计 $18.98 \mathrm{~km}^{2}$,水田、旱田、草原开发规模总计 $18.93 \mathrm{~km}^{2}$.

前郭片 (含红星片) 具有排向二松的独立系统; 而大布苏片尾水泄人大布苏泡, 对查干湖无直接影响, 其 它 9 片尾水都泄向查干湖方向, 构成大面积风险源. 该 9 片的面积为 $7.70 \mathrm{~km}^{2}$, 占总面积的 $41 \%$. 其中盐渍 化土地面积达 $6.17 \mathrm{~km}^{2}$, 占 $80.1 \%$. 在这些盐渍化土地中将开发水田 $5.63 \mathrm{~km}^{2}$, 占盐渍土总面积的 $91 \%$. 可 见, 盐碱地围湖造田规模之宏大、盐渍化程度之严重, 在中国乃至世界上史无前例, 对查干湖必然构成范围 较大的风险源区.

2.2.3 风险物质数量巨大 风险物质主要是盐碱地开发成水田所释放的可溶盐类与农药残留物. 郭斌认为 农药残留物对查干湖水环境影响不大 ${ }^{[18]}$, 但灌区可溶盐释放量巨大, 对查干湖水质影响最为关键. 为评估这一 风险, 需要计算其年可溶盐释放率及释放量. 据大安古河道万亩试验区多年试验结果, 不同盐化土壤表层经过一年 种稻洗碱后的盐碱脱盐率(释放率) : 轻度、中度和高度盐化草甸土分别为 $33.33 \% 、 59.70 \%$ 和 62.00\% (表 4) ${ }^{[19]}$.

表 4 种稻第 1 年可融盐释放率及释放量*

Tab. 4 The releasing rate and quantity of saline-alkaline in the first year of planting rice

\begin{tabular}{ccccccc}
\hline 类型 & 土壤深度 $/ \mathrm{cm}$ & 灌前含盐量 $/ \%$ & 灌后含盐量 $/ \%$ & 效果 & 释放率 $/ \%$ & 释放量 $/\left(\mathrm{kg} / \mathrm{hm}^{2}\right)$ \\
\hline 轻度盐化草甸土 & $0 \sim 30$ & 0.18 & $0.12(1$ 次泡田 $)$ & 接近非盐渍土 & 33.33 & 1257.6 \\
中度盐化草甸土 & $0 \sim 30$ & 0.35 & $0.14(2$ 次泡田 $)$ & 进人轻度盐渍土 & 59.70 & 2445.3 \\
重度盐化草甸土 & $0 \sim 30$ & 0.58 & $0.22(3$ 次泡田 $)$ & 进人轻度盐渍土 & 62.00 & 2836.5 \\
平均 & $0 \sim 30$ & 0.37 & 0.16 & 轻度盐渍土 & 51.68 & 2179.8 \\
\hline
\end{tabular}

* 释放量计算式: $Q=S \cdot Y \cdot M \cdot q ; Q$ 为释放量; $S$ 为片区面积; $Y$ 为片区盐碱土类 (\%); $M$ 为含盐量 (\%); $q$ 为释放 率 $(\%)$.

三类苏打盐渍土的平均灌前含盐量为 $0.37 \%$ (表 4). 经计算, 在经过第一年不同泡田次数的种稻洗碱后, 盐碱 的平均释放率为 $51.68 \%$, 与陈恩风等的研究结果 (释放率为 $50 \%$ ) 接近 ${ }^{[20]}$. 古河道试验区每亩平均排盐量 是 $145.32 \mathrm{~kg}$, 恰好反映了三类盐渍土复区状态, 具有代表性. 那么, 以释放量为 $2179.8 \mathrm{~kg} / \mathrm{hm}$ 、面积为

(1) 吉林省水利水电勘测设计研究院. 松原灌区项目建议书,2010:1-126. 
$5.63 \mathrm{~km}^{2}$ 的排盐总量达到 $1.23 \times 10^{8} \mathrm{~kg}$. 湖泊容积 (海拔 $130.0 \mathrm{~m}$ ) 按 $5.15 \times 10^{8} \mathrm{~m}^{3}$ 计算, 这些可溶盐类人湖, 可使湖的含盐量增加 $2.4 \%$, 达到 $3.4 \%$, 变成一个中度碱湖,生态系统严重退化.

2.2.4 中、高级风险区比例高 为评估保护湖区生态安全, 依据开发 (风险源) 对查干湖的接触关系、污染源 (排泄盐碱) 的强度等要素以及有害独立元素, 对沿湖岸带进行了风险区划分. 本文基于农业开发性质, 以前 2 个要素最为重要,并进行四级划分.

1) 低级风险区: 拟扩建的前郭灌区与查干湖之间有连续的河流一级阶地分隔, 地面标高 $140 \sim 160 \mathrm{~m}$, 平均宽度约 $1.5 \mathrm{~km}$. 组成物质为亚砂土一亚黏土, 渗透性低, 阻隔了地表水与湖水的联系. 水田扩展开发后, 排灌系统进一步完善,红星片排水纳人其中. 因此,该段属于低级风险区.

2) 中级风险区: 有字片与戎字片北段为原有旱田, 采用滴灌基本无排水. 与湖间有断续岗状高地 (一级 阶地自然堤), 只要适当加固, 可阻挡开发后的可溶盐流人湖中. 因此该段属于中级风险区.

3) 高级风险区: 洪字片、余字片与潜字片涉及收字井至辰字井之间的范围, 沼泽和农田直接与湖体接 触, 土地盐碱化较重, 中、重度盐渍化土占 $85 \%$, 产出盐碱较多, 对湖体会有较大风险. 其次, 辰字井至刘家围 子之间, 湖体与即将开发的洪字片水田区呈开放状态, 故定为高级风险区.

4) 最高级风险区: 龙海片涉及刘家围子与姜家围子之间的查干湖湖口带, 即霍林河口洪泛带, 两者呈开 放型接触, 且坡降向湖口倾斜. 开发水田面积大, 中、重度盐渍土高达 $90 \%$, 因而盐碱最重, 有连片碱漠, 属于 最高级风险区.

2.2.5 风险物质具有累积效应 苏打盐碱土种稻开发中可溶盐具有高释放率特性. 由重度向中度和轻度盐 渍土转化的速度也较快. 大安古河道万亩试验区证明, 苏打盐类还具有较其他盐类更高的水溶特性. 土壤中 可溶盐的释放是一个较长的过程, 尽管第一年的释放量较大, 占土壤表层含盐量的 $50 \%$ 左右, 但之后按降幂 递减. 根据大安古河道万亩试验区的结果, 下一年可溶盐的释放量是上一年的 $25 \%$ 左右. 据此计算, 若查干 湖无控制地接受排放尾水,则水田开发第 5 年,查干湖将变成重碱性湖,生态系统严重恶化.

\section{3 风险控制机制与防范措施}

\section{1 建立湿地缓冲区, 避免尾水直排入湖}

3.1 .1 建立缓冲区的必要性 如上所述, 沿湖围筀产生的大量可溶盐, 会从中、高及最高级三类风险区进人 湖中, 导致严重生态后果. 所以, 尽管查干湖有良好库容, 尾水也不能直排人湖. 鉴于此, 本文拟定在湖的外 围建立相应的湿地处理系统一一生态缓冲区, 来承泄排放尾水, 待尾水进人沼泽处理系统后, 得到降解和沉 淀, 盐分被芦苇等耐盐植物吸收, $\mathrm{pH}$ 值降低. 当水质满足湖水水质要求时, 再人湖补给. 达到控制和化解生 态风险的目的.

3.1 .2 缓冲区结构特征及功能 针对中、高及最高级三类风险区, 在湖滨盐碱沼泽设计了 5 个水质处理系 统. 这种以储蓄含盐水体为主的湿地处理系统, 与水污染湿地处理系统在结构上有明显不同, 不必考虑床体 结构, 而主要是利用其区位与空间特性, 以芦苇为主要生物群落, 依托阶地和天然堤等地貌条件, 并实施必 要的矮堤工程, 切断可溶盐直接入湖径流, 以满足容纳相应开发片泄水量的原则 (表 5 ).

表 5 松原灌区尾水的查干湖湿地处理系统

Tab. 5 The wetland treatment systems of Lake Chagan for Songyuan Irrigation tail water

\begin{tabular}{|c|c|c|c|c|c|}
\hline 湿地处理系统 & 位置 & 面积 $/ \mathrm{hm}^{2}$ & $\begin{array}{c}\text { 容积/ } \\
\left(\times 10^{4} \mathrm{~m}^{3}\right)\end{array}$ & 构造 & 排水区片 \\
\hline $\begin{array}{l}\text { 霍林河口湿地 } \\
\text { (含季节河道) }\end{array}$ & 查干湖西 & 13330.0 & 7874 & $\begin{array}{l}\text { 北为大安灌区堤防, 南为阶地天然堤; 徐新屯至后 } \\
\text { 盈子屯设堤长 } 5230 \mathrm{~m} \text { 、堤高 } 2.2 \mathrm{~m} \text { 、顶宽 } 2.0 \mathrm{~m}\end{array}$ & $\begin{array}{l}\text { 龙沼片 } \\
\text { 水字片 }\end{array}$ \\
\hline 邹家围子湿地 & 查干湖西 & 3000.0 & 1500 & 利用湖滨天然堤和铁路路基形成闭流湿地 & 洪字片 \\
\hline 辰字村湿地 & 查干湖西南 & 1500.0 & 800 & 辰字村-收字村建堤防, 高 $1.6 \mathrm{~m}$ 、顶宽 $2 \mathrm{~m}$ & 余字片 \\
\hline 云字泡湿地 & 查干湖南 & 1172.5 & 1345 & 设长 $1000 \mathrm{~m}, 2100 \mathrm{~m}$ 围堤 & 有字片 \\
\hline 蒙古屯湿地 & 查干湖东南 & 1092.0 & 655 & 设长 $1013 \mathrm{~m}$ 围堤, 高 $1.5 \mathrm{~m}$ 、顶宽 $2 \mathrm{~m}$ & 戎字片 \\
\hline
\end{tabular}


5 个缓冲区目前都是严重退化的盐沼, $\mathrm{pH}$ 一般为 $8 \sim 10$, 属于中、重度苏打盐碱地环境, 而水田开发的盐 碱地主要为轻一中一重度盐碱地复区, 平均为中度, 在经过泡田洗碱等技术措施后, 尾水的含盐量在中度以 下. 因此, 总体上尾水进人缓冲区后不会加重其盐碱度, 甚至还会有一定的稀释效果. 湿地处理系统经过约 3 到 5 年运行, 尾水盐度降低, 湿地生态环境都将得到优化. 因此,这种生态控制是可行的.

\section{2 滚动开发,合理调控尾水排放浓度和时间}

在大安古河道万亩试验区, 本文总结出不同类型苏打盐渍土种稻洗碱的转化规律 (表 6 ). 盐渍土淡化过 程的转变规律表明, 苏打盐类水溶性高、释放快. 为了平缓可溶盐的释放峰值, 提出了滚动开发的方案, 即制 定合理开发额度, 每年约 $0.67 \mathrm{~km}^{2}$, 并将不同盐渍土复区实施轻、中、重度 (含碱土与盐土) 配置开发, 这样便 使灌区释放可溶盐的平均浓度降低到中度或以下,并限制了释放总量. 由于作为湿地处理系统的退化沼泽, 相当于中度盐化土环境, 当尾水低于中度当量时, 则一般不会加重缓冲区的盐渍化程度. 再考虑种稻过程中 可溶盐的释放量及浓度服从降幂趋势, 因而湿地处理系统的生态环境也随之进人恢复时期, 并允许排人湖 中发挥补水功能.

表 6 松嫩平原苏打盐渍土种稻洗碱后的类型转变时间

Tab. 6 The transform time of saline-alkaline soil type in Songnen Plain

\begin{tabular}{ccccc}
\hline & 轻度盐化草甸土 & 中度盐化草甸土 & 重度盐化草甸土 & 重度盐化草甸土-盐土、碱土复区 \\
\hline 转变时间/a & 2 & $2 \sim 3$ & $4 \sim 5$ & $>6$ \\
转化后土壤类型 & 弱碱性土(接近非盐化土) & 轻度盐渍化土 & 轻度盐渍化土 & 轻度盐渍化土 \\
\hline
\end{tabular}

\section{3 合理利用湖泡随机排水, 减小查干湖压力}

灌区湖泡广布. 为减轻对查干湖的生态压力, 设计中将用 30 余个湖泡用以承担灌片的泄水 (表 7). 这些随 机承泄区具有重要承泄功能, 可使大布苏灌片和安字灌片全部尾水内泄, 洪字泡可容纳水字、余字及洪字灌片 的大部分泄水, 超过部分再泄人邹家围子湿地系统. 可见,这些湖泡的承泄对查干湖区的分流功能是显著的.

表 7 松原灌区其它承泄湖泡特征及储量

Tab. 7 The other lakes for keeping tail water from Songyuan Irrigation

\begin{tabular}{ccccccc}
\hline 序号 & 名称 & 位置 & 面积 $/\left(\times 10^{6} \mathrm{~m}^{2}\right)$ & 平均深度 $/ \mathrm{m}$ & 可储水量 $/\left(\times 10^{6} \mathrm{~m}^{3}\right)$ & 承泄灌片 \\
\hline 1 & 大布苏泡 & 大布苏镇 & 60.0 & 1.5 & 60.0 & 大布苏灌片全部 \\
2 & 孝字泡 & 才字乡东 & 1.2 & 0.5 & 1.2 & 安字灌片全部 \\
3 & 大字泡 ${ }^{*}$ & 身字村 & 8.1 & 1.0 & 8.1 & 安字灌片全部 \\
4 & 女字泡 & 女子井 & 1.0 & 0.5 & 1.0 & 安字灌片全部 \\
5 & 竟字泡 & 竟字井 & 0.6 & 0.5 & 0.5 & 安字灌片全部 \\
6 & 唱字泡 & 唱字井 & 1.0 & 0.5 & 1.0 & 安字灌片全部 \\
7 & 张家泡 & 大金字井 & 4.0 & 1.0 & 4.0 & 龙海灌片南部 \\
8 & 赵家泡 & 赵家围子 & 1.5 & 0.6 & 1.5 & 龙沼灌片部分 \\
9 & 洪字泡 & 余字乡北 & 20.2 & 1.5 & 20.2 & 洪字灌片部分 \\
10 & 双字泡 & 余字乡南 & 1.3 & 0.6 & 1.3 & 余字、水字灌片部分 \\
11 & 云字泡 & 云字井村 & 1.1 & 0.5 & 1.1 & 戎字灌片部分 \\
\hline
\end{tabular}

* 大字泡外有寸字泡、赞字泡、鞠字泡、滨字泡、率字泡、唐子泡、陶子泡等小于 $1.0 \mathrm{~km}^{2}$ 的小湖泡.

\section{4 结语}

查干湖是微碱性湖泊, 属于国家自然保护区, 具有半干旱复合生态系统典型性和生物多样性. 但其生态 系统脆弱,增加水量、改善水质是生态保护的关键.

拟建松原灌区将对查干湖外围的苏打盐碱地进行大面积围垦, 所产生大量较高浓度的水田尾水, 将对 查干湖构成生态风险. 而且尾水具有风险源广大、风险物质量大和集聚速度快等特点, 若尾水直接排向查干 湖,将使其变为中度碱湖, 对查干湖的生态安全构成严重威胁. 
为了防止这种后果的发生, 在分析排水模式, 计算尾水含盐浓度、产盐率和总量基础上, 通过风险区划 分, 首次提出灌区尾水不直接人湖, 而是利用湖泊外围的退化湿地, 构建 5 个湿地尾水处理系统的构想. 这 些尾水处理系统即是查干湖的生态缓冲区, 尾水进人后得到净化、降解和沉淀. 伴随水田排盐量逐渐减少, 灌区运行一定时期后, 水质便得到改善, 那时再人湖泊发挥补水效应. 既可防止湖水污染, 又可保证灌区开 发可行. 这也是湿地处理系统在大规模盐碱地农田工程的首次尝试, 在国内外尚未见先例. 同时, 充分利用 大量碱湖泡作为随机承泄区, 就地容储尾水, 减轻查干湖汇水压力. 采取这些技术措施, 既能够保证查干湖 生态安全, 又能够使松原灌区建设具有可行性.

致谢: 参加早期调查的还有郝凌云、刘景双、杨富亿、张晓平、王其纯等研究员; 王国石、顾斌等工程师, 罗金 明、罗新正博士等参加了部分工作, 谨此一并表示感谢.

\section{5 参考文献}

[1] 孙广友. 东北西部建设水稻基地带动区域综合开发的建议. 见: 孙广友等编. 松嫩平原古河道农业工程研究. 长春: 吉林科学技术出版社,2007:425-458.

[ 2 ] 申晋利, 张军龙. 基于面向对象分类方法的查干湖地区生态环境变化遥感分析. 地球科学与环境, 2009, 31 (2): 212-215.

［3］代雪静,田 卫. 查干湖水质污染分析及控制途径. 干旱区资源与环境,2011,25(8):182-187.

[ 4 ] 刘 强,魏春风. 查干湖国家自然保护区生态安全评价研究. 长春工程学院学报,2010,(2):50-53.

[ 5 ] 阎百兴,邓 伟,汤 洁. 松嫩平原西部稻田汇水中污染物的输出规律. 上海环境科学,2002,10(21):583-587.

[ 6] 大安古河道综合开发研究课题组. 大安古河道综合开发初步可行性研究. 见: 孙广友等编. 松嫩平原古河道农业工 程研究. 长春: 吉林科学技术出版社,2007:283-285.

[ 7 ] 孙广友, 李秀军. 关于生态灌区规划理论体系的探讨一以大安古河道灌区为例. 见: 孙广友等编. 松嫩平原古河 道农业工程研究. 长春: 吉林科学技术出版社,2007:395-405.

[ 8 ] 易富科. 嫩江大安古河道草地区域生物多样性特点及开发利用. 见: 何岩等编. 东北区域农业综合开发研究. 北京: 科学出版社,2001:210-213.

[9] 孙广友. 松辽平原中部第四纪地壳运动与平原发育——兼论松辽分水岭的形成. 见: 东北平原第四纪自然环境形 成与盐化课题组编. 中国东北第四纪自然环境形成与演化. 哈尔滨: 哈尔滨地图出版社, 1990:44-50.

[10］王苏民,窦鸿身. 中国湖泊志. 北京:科学出版社,1998:519-520.

[11] 李秀军. 松嫩平原西部土地盐碱化与农业可持续发展. 见: 何岩等编. 东北区域农业综合开发研究. 北京: 科学出版 社, 2001:26-31.

[12] 张树文,张养贞,李 颖等. 东北地区土地利用/覆被时空特征分析. 北京:科学出版社,2006:316.

[13] 孙广友, 王海霞, 于少鹏等. 强胁迫力使脆弱环境突变: 松辽平原百年开发史例证. 第四纪研究, 2004, 24 (6): 663-670.

[14] 王海霞, 万忠娟, 于少鹏等. 松嫩平原距今 150 年湿地景观结构重建. 东北师大学报: 自然科学版, 2004,36(2): 75-81.

[15] 孙广友, 华润葵, 邓 伟等. 嫩江右岸大安古河道的发现及意义. 见: 中国地理学会地貌与第四纪专业委员会编. 地 貌学术讨论会文集. 北京: 地震出版社,1993:4049.

[16] 罗新正, 朱 坦, 孙广友等. 大安古河道综合开发生态工程地质地貌环境可行性论证. 地理科学, 2003, (3): 348-353.

[17] 潘 锋, 孙 逊. 为盐碱地变为国家粮食基地提供强力支撑一一记松嫩古河道种稻治碱试验研究 20 年. 中国科学 报,2012.1.1[B12].

[18] 郭 斌. 松原灌区稻田农药对查干湖环境影响研究 [ 学位论文]. 长春: 中国科学院东北地理与农业生态研究所, $2012: 1-5$.

[19] 大安古河道综合开发研究课题组. 大安古河道综合开发万亩试验研究. 见: 孙广友等编. 松嫩平原古河道农业工程 研究. 长春: 吉林科学技术出版社,2007:341-394.

[20］陈恩风,王汝槦,胡思敏等. 吉林省前郭旗灌区苏打盐渍土的改良. 土壤学报, 1962,10(2):301-314. 